Available online at http://jurnal.stmikroyal.ac.id/index.php/jurteksi

\title{
PENILAIAN RESIKO PADA SISTEM MONITORING KEGIATAN BELAJAR MENGAJAR DI PERGURUAN TINGGI SWASTA
}

\author{
Yayuk Ike Melani ${ }^{1 *}$, Mahmud $^{2}$ \\ ${ }^{1}$ Sistem Informasi, STMIK PalComTech Palembang \\ ${ }^{2}$ Informatika, STMIK PalComTech Palembang \\ email: *yayuk_ike@palcomtech.ac.id
}

\begin{abstract}
The background of this research is that some of the risks of using technology that are classified as dangerous are often ignored by users of the monitoring system for learning activities at private universities so that there are several obstacles such as not being able to open the system because the system is hacked by irresponsible parties, the computer network used is often disrupted so that hampers the operational process, and the level of computer security is still relatively weak. This study aims to measure the likelihood of threats and risk impacts on the teaching and learning activity monitoring system and to provide recommendations for risk control of security problems that could become a threat that causes losses to universities. The framework used as a tool to measure the level of threat and risk impact is to use the NIST Special Publication 800-30r-1 framework. The framework of the NIST Special Publication 800-30r1 has nine phases in carrying out risk assessments, namely introduction of system characteristics, recognition of threats, recognition of vulnerabilities, analysis of handling systems, determining likelihood, determining impact, risk determination, recommending control and determination of results. There are six risk assessment systems for monitoring learning activities at private universities, two of which are high so they are classified as very dangerous and the rest are moderate. The results of this study are used as a reference in making risk control standard documents as a form of improving the quality of a private university.
\end{abstract}

Keywords: Monitoring System; NIST Spesial Publication 800-30r1; Risk Assessment.

Abstrak: Latarbelakang penelitian ini adalah resiko penggunaan teknologi yang tergolong berbahaya sering tidak dihiraukan oleh pengguna sistem monitoring kegiatan belajar pada perguruan tinggi swasta sehingga terjadi beberapa kendala seperti tidak bisa membuka sistem karena sistem diretas oleh pihak yang tidak bertanggung jawab, jaringan komputer yang digunakan sering terganggu sehingga menghambat proses operasional, serta tingkat keamanan komputer yang masih tergolong lemah. Penelitian ini mempunyai tujuan yaitu mengukur seberapa besar kemungkinan terjadi ancaman dan dampak resiko terhadap sistem monitoring kegiatan belajar mengajar serta memberikan rekomendasi pengendalian resiko dari permasalahan keamanan yang bisa menjadi suatu ancaman yang menimbulkan kerugian pada perguruan tinggi. Framework yang digunakan sebagai alat untuk mengukur tingkat ancaman dan dampak resiko adalah menggunakan kerangka kerja NIST Special Publication 800-30r-1. Kerangka kerja NIST Special Publication 800-30r-1 ini mempunyai sembilan fase dalam melakukan penilaian resiko yaitu pengenalan karakteristik sistem, pengenalan ancaman, pengenalan kerentanan, analisis penanganan sistem, menentukan kemungkinan terjadi (likelihood), menentukan dampak (impact), risk determination, merekomendasikan pengendalian dan penetapan hasil. Penilaian resiko sistem monitoring kegiatan belajar pada perguruan tinggi swasta ada enam resiko yang dua diantaranya termasuk tinggi sehingga digolongkan sangat berbahaya dan selebihnya termasuk sedang. Hasil dari penelitian ini digunakan sebagai acuan dalam pembuatan dokumen standar pengendalian resiko sebagai bentuk peningkatan mutu suatu perguruan tinggi swasta.

Kata kunci: NIST Spesial Publication 800-30r; Penilaian Resiko; Sistem Monitoring 
Available online at http://jurnal.stmikroyal.ac.id/index.php/jurteksi

\section{PENDAHULUAN}

Perkembangan teknologi yang luar biasa beberapa dekade membuat semua pekerjaan menjadi lebih cepat dan akurat. Salah satu yang menerapkan teknologi informasi adalah perguruan tinggi. Tidak hanya perguruan tinggi negeri tetapi perguruan tinggi swasta pun juga menerapakan teknologi informasi sebagai alat dalam proses pembelajaran. Tata kelola TI hendaknya mendapatkan perhatian serta dukungan oleh stakeholder [1]. Keamanan adalah aspek penting dalam pengelolaan TI, mengingat keamanan dalam bidang komputer berkembang dengan pesat [2].

Permasalahan yang diakibatkan oleh keamanan sistem membuat kerugian. Keamanan informasi adalah suatu upaya untuk mengamankan aset informasi yang dimiliki. Kebanyakan orang mungkin akan bertanya, mengapa "keamanan informasi" dan bukan "keamanan teknologi informasi" atau IT Security [3].

Pemanfaatan teknologi dan sistem informasi seharusnya mendapatkan perhatian sehubungan dengan resiko yang mempunyai peluang akan datang sehingga pemanfaatan sistem informasi dan teknologi menjadi kurang berhasil [4].

Penelitian ini difokuskan pada penilaian resiko terhadap penggunaan teknologi dari sistem monitoring kegiatan belajar mengajar yang ada pada salah satu perguruan tinggi swasta di Palembang. Setiap proses kegiatan belajar mengajar diperlukan pengawasan terhadap teknologi yang digunakan agar kegiatan belajar mengajar berjalan dengan lancar. Seiring berjalannya waktu dan penggunaan teknologi semakin besar, terdapat beberapa kejahatan komputer yang dilakukan oleh user. Kejahatan komputer digolongkan dari yang hanya mengesalkan sampai ke tahap sangat berbahaya. Penelitian sebelumnya mengungkapkan bahwa yang dibuat merupakan sistem meliputi menyebabkan tidak keseragaman dalam aturan proses PPDB. Hal ini menyebabkan resiko yang cukup besar pula. Dengan adanya manajemen resiko, dapat mengatur dan mengelola segala sesuatu terkait dengan kegiatan penilaian resiko, mitigasi resiko dan evaluasi pelaksanaannya [5].

Penelitian sebelumnya pernah memaparkan bahwa menganalisis resiko TI pada program Human Resource Management System (HRMS) menggunakan ISO 31000. Analisis ini menggunakan tahapan-tahapan seperti penilaian risiko yang terdiri dari tahap identifikasi, analisis, dan tahap evaluasi risiko hingga tahap perlakuan risiko dalam penelitiannya [6]. Modal kritis yang melakukan pemahaman pada Unit Pengelola Sistem Informasi dan Kehumasan Fakultas Ilmu Komputer adalah FILKOM Apps dan Infrastruktur Data dan Jaringan. Ada tiga area keamanan yang bertanda kuning adalah Pengendalian Akses Fisik, Autentikasi dan Otorisasi, serta Manajemen Kerentanan sedangkan yang lainnya berwarna merah [7]. Sebagian orang masih belum menyadari bahwa kegagalan dalam proyek TI dapat menyebabkan resiko serius. Manajemen resiko TI memerlukan yang tepat tujuan bisnis dapat dicapai. Untuk meminimalisir resiko, beberapa instansi pemerintah maupun swasta harus dapat menyusun langkah-langkah penggunaan layanan TI agar dapat berfungsi dengan baik [8].

Tujuan dari penelitian ini adalah mengukur seberapa besar kemungkinan terjadi ancaman dan dampak resiko terhadap sistem monitoring kegiatan belajar 
Available online at http://jurnal.stmikroyal.ac.id/index.php/jurteksi

mengajar serta memberikan rekomendasi pengendalian resiko dari permasalahan keamanan yang bisa menjadi suatu ancaman yang menimbulkan kerugian pada perguruan tinggi.

\section{METODE}

\section{Teknik Pengumpulan Data}

Penelitian ini menggunakan Teknik wawancara dan observasi sebagai teknik pengumpulan data. Wawancara adalah teknik berkomunikasi atau beriinteraksi untuk mendapatkan informasi dengan cara bertanya dan menjawab yang dilakukan oleh peneliti dan informan atau subjek penelitian. Adanya kemajuan teknologi seperti membuat wawancara dapat dilakukan tanpa tatap muka, yakni melalui media elektronik. Pada dasarnya wawancara merupakan kegiatan untuk memperoleh informasi secara rinci tentang sebuah persoalan yang diangkat dalam penelitian. Atau, merupakan proses memberikan bukti terhadap informasi atau keterangan yang telah diperoleh lewat teknik yang lain sebelumnya [9]. Wawancara dilakukan dengan mewawancarai user yang yang bertanggung jawab atas aplikasi. Data yang didapat berupa informasi ancaman apa saja yang pernah menyerang aplikasi.

Pengumpulan data selanjutnya yang dilakukan adalah observasi. Observasi sebagai kegiatan mencatat suatu proses kejadian dan merekamnya untuk tujuan ilmiah. Observasi merupakan kumpulan data berdasarkan semua kemampuan daya tangkap pancaindera manusia [10]. Data yang didapat adalah informasi dari hardware dan software yang digunakan untuk scanning jika terjadi hacking dan phissing, informasi hardware yang dipakai, informasi bagaimana penanganan jika ada an- caman, serangan apa saja yang pernah terjadi.

\section{Mekanisme Penilaian Resiko}

Mekanisme penilaian resiko menggunakan menggunakan kerangka kerja NIST Spesial Publication 800-30r1. Kerangka kerja NIST Spesial Publication 800-30r-1 adalah sebuah kerangka kerja yang merupakan panduan untuk menjalankan sebuah data yang mempunyai kerentanan. Kerangka kerja ini mempunyai peranan dalam penilian resiko karena didalam proses kerangka kerja ini pengguna penjelasan pengetahuan keamanan yang sesuai dan mendalam, bentuk sumber daya yang terstruktur, pengetahuan keamanan informasi dapat diterima oleh penerima resiko, penentuan ancaman terhadap teknologi dapat diketahui dengan mudah, pemberian keputusan untuk setiap ancaman dan bahaya yang telah diperiksa [11]. Untuk menjaga kapabilitas misi dalam menjaga sistem TI da data yang mendukung misi organisasi, NIST memperkenankan TI untuk menyimbangkan biaya operasional [12].

NIST merupakan proses yang memperkenankan manajer TI Kerangka kerja ini mengeluarkan rekomendasi melalui publikasi khusus 800-30r1 tentang Risk Management Guide for Information Technology System. Ada tiga proses dalam manajemen resiko yaitu Risk Assessment, Risk Mitigation dan Evaluation and Assessment. Tetapi, proses yang digunakan penulis dalam penelitian ini adalah membahas risk assessment dari sistem informasi akademik. Risk assessment atau penilaian risiko adalah proses awal yang dilakukan dalam metodologi manajemen risiko [13]. Beberapa organisasi menggunakan asessment untuk mengetahui seberapa banyak potensi ancaman dan risiko yang terkait dengan teknologi informasi di seluruh SDLC- 
Available online at http://jurnal.stmikroyal.ac.id/index.php/jurteksi

nya. Keluaran dari proses ini membantu mengetahui pengendalian yang tepat mengurangi atau menghilangkan risiko selama proses mitigasi risiko. Penilaian resiko dari framework NIST 800-30r1 mempunyai sembilan fase yaitu :

\section{Pengenalan Karakteristik Sistem}

Sistem teknologi informasi mencakup perangkat keras, perangkat lunak, infrastrktur, data dan informasi user yang terlibat dalam pengelolaan dan penggunaan sistem.

\section{Pengenalan Ancaman}

Melakukan pengenalan bahaya terhadap kelemahan sistem teknologi informasi yang berasal dari dalam maupun luar organisasi serta lingkungan.

\section{Pengenalan Kerentanan}

Melakukan pengenalan kerentanan (vulnerability) pada mekanisme keamanan, desain, implementasi, pengendalian baik luar maupun dalam terhadap sistem sehingga menghasilkan kesalahan terhadap kebijakan keamanan sistem.

\section{Analisis Penanganan Sistem}

Melakukan pengkajian terhadap beberapa pengendalian yang sudah diterapkan atau direncanakan untuk direncanakan kembali oleh organisasi dalam upaya menghilangkan kemungkinan terjadinya suatu ancaman yang dapat menyerang sistem yang digunakan.

\section{Menentukan Kemungkinan Terjadi (Likelihood)}

Menentukan kemungkinan terjadi (likelihood) bertujuan untuk mengevaluasi keseluruhan kemungkinan terjadi kerentanan terhadap serangan yang dilakukan oleh lingkungan sekitar. Penilaian skala untuk kemungkinan terjadi ada 4 tabel yaitu skala yang mengukur kemungkinan terjadi pada penyusup(adversarial), mengukur kemungkinan terjadi bukan karena penyusup(non-adversarial), mengukur kemungkinan terjadi yang mengakibatkan dampak buruk, dan yang terakhir itu skala keseluruhan dari kemungkinan terjadi. Tabel 1 menunjukan gambaran dari kemungkinan terjadi karena penyusup.

Tabel 1. Kemungkinan Terjadi Resiko

\begin{tabular}{ll}
\hline Deskripsi Kemungkinan Terjadi Resiko \\
\hline Tinggi & $\begin{array}{l}\text { Sumber ancaman sangat mahir } \\
\text { pencegahan yang dilakukan } \\
\text { tidak efektif lagi }\end{array}$ \\
\hline Sedang & $\begin{array}{l}\text { Sumber ancaman dapat } \\
\text { menembus dinding pertahanan } \\
\text { sistem tetapi tidak dapat } \\
\text { merusak sistem }\end{array}$ \\
\hline Rendah & $\begin{array}{l}\text { Sumber ancaman tidak dapat } \\
\text { menembus keamanan }\end{array}$ \\
\hline Sumber: NIST SP 800-30 rl
\end{tabular}

Menganalisis Dampak Resiko

Melakukan analisis dampak negatif terhadap keberhasilan penyerangan vulnerability sistem TI. Seperti loss of integrity, loss of availability, dan loss of confidentiality. Pengukuran dampak dari risiko TI dapat dilakukan secara kualitatif. Dampak tersebut dapat diklasifikasikan menjadi tiga bagian yaitu: tinggi, sedang dan rendah. Dampak atau impact yang digunakan dalam melakukan penilaian resiko telah tersedia didalam kerangka kerja NIST SP 800-30r-1. Skala mengukur dampak resiko yang terlihat pada tabel 2 . 
Available online at http://jurnal.stmikroyal.ac.id/index.php/jurteksi

Tabel 2. Skala Penilaiain Dampak

\begin{tabular}{|c|c|}
\hline & Deskripsi Dampak \\
\hline Tinggi & $\begin{array}{l}\text { Menyebabkan kerusakan } \\
\text { parah atau hilangnya ke- } \\
\text { mampuan untuk mening- } \\
\text { katkan misi dari lembaga } \\
\text { yang mengakibatkan tidak } \\
\text { dapat melakukan satu atau } \\
\text { lebih dari fungsi utama sis- } \\
\text { tem. }\end{array}$ \\
\hline Sedang & $\begin{array}{l}\text { Menyebabkan penurunan } \\
\text { yang signifikan dalam } \\
\text { meningkatkan misi dan } \\
\text { lembaga yang mengakibat- } \\
\text { kan tidak dapat melakukan } \\
\text { satu atau lebih dari fungsi } \\
\text { utama sistem. }\end{array}$ \\
\hline Rendah & $\begin{array}{l}\text { Menyebabkan degradasi } \\
\text { dalam meningkatkan misi } \\
\text { lembaga tidak dapat } \\
\text { melakukan satu atau lebih } \\
\text { dari fungsi utama sistem, } \\
\text { tetapi efektifitas fungsi } \\
\text { berkurang. }\end{array}$ \\
\hline
\end{tabular}

\section{Risk Determinan}

Penetapan tingkatan risiko dari sistem teknologi informasi yang merupakan pasangan ancaman merupakan suatu fungsi, yaitu keinginan suatu sumber ancaman menyerang vulnerability dari sistem teknologi informasi.

Matriks tingkat resiko yang digunakan adalah $3 \mathrm{X} 3$ yaitu untuk penentuan kemungkinan terjadi ancaman yang terdiri dari tinggi, sedang dan rendah. Kemudian untuk penentuan dampak ancaman terdiri dari tinggi, sedang dan rendah. Dari penentuan keseluruhan maka didapat hasil apakah termasuk kedalam level yang rendah atau yang tinggi. Kemungkinan terjadi ancaman mempu- nyai skala level yaitu 1 untuk tinggi, 0,5 untuk sedang, dan 0,1 untuk rendah. Nilai dari dampak ancaman yaitu 100 untuk tinggi, 50 untuk medium dan 10 untuk rendah. Tingkat resiko kombinasi antara kemungkinan terjadi dan dampak dapat dilihat pada gambar 1 .

\begin{tabular}{|c|c|c|c|}
\hline \multirow[b]{2}{*}{$\begin{array}{c}\text { Threat } \\
\text { Likelihood }\end{array}$} & \multicolumn{3}{|c|}{ Impact } \\
\hline & & & $\begin{array}{l}\text { High } \\
(100)\end{array}$ \\
\hline High (1.0) & $\begin{array}{c}\text { Low } \\
10 \times 1.0=10\end{array}$ & $\begin{array}{c}\text { Medium } \\
50 \times 1.0=50\end{array}$ & $\begin{array}{c}\text { High } \\
100 \times 1.0=100\end{array}$ \\
\hline Medium (0.5) & $\begin{array}{c}\text { Low } \\
10 \times 0.5=5\end{array}$ & $\begin{array}{c}\text { Medium } \\
50 \times 0.5=25\end{array}$ & $\begin{array}{c}\text { Medium } \\
100 \times 0.5=50\end{array}$ \\
\hline Low (0.1) & $\begin{array}{c}\text { Low } \\
10 \times 0.1=1\end{array}$ & $\begin{array}{c}\text { Low } \\
50 \times 0.1=5\end{array}$ & $\begin{array}{c}\text { Low } \\
100 \times 0.1=10\end{array}$ \\
\hline
\end{tabular}

Gambar 1. Skala Penentuan Resiko

\section{Merekomendasikan Pengendalian}

Memberikan saran pencegahan untuk mengurangi tingkatan risiko sistem teknologi informasi serta data sehingga mencapai tingkatan yang dapat diterima.

\section{HASIL DAN PEMBAHASAN}

Terdapat beberapa tahapan-tahapan yang dilakukan untuk mengantisipasi kemungkinan terjadinya resiko adalah sebagai berikut:

\section{Karakteristik Sistem}

Perangkat keras yang digunakan berupa PC yang mempunyai server lokal dan server luar yaitu cloud untuk membackup data-data yang diolah didalam aplikasi sintana. Software yang digunakan berupa linux free BSD.

\section{Pengenalan Ancaman}

Ancaman terhadap sistem monitoring kegiatan belajar mengajar adalah orang dalam yang pernah mempunyai akses kedalam sistem, sistem operasi yang usang, kebakaran yang disebabkan human error, virus malware, jamming, serangan cyber, rusaknya media penyimpanan seperti hardisk yang ada pada PC yang digunakan. 
Available online at http://jurnal.stmikroyal.ac.id/index.php/jurteksi

Tabel 3. Indentifikasi Kerentanan

\begin{tabular}{|c|c|}
\hline Tipe Resiko & Kerentanan \\
\hline $\begin{array}{l}\text { Pengguna sistem monitoring yang } \\
\text { merupakan orang }\end{array}$ & $\begin{array}{l}\text { - Salah satu penyerangan yang dilakukan yaitu } \\
\text { menggunakan kata kunci secara paksa untuk } \\
\text { melakukan pencurian data pada sistem }\end{array}$ \\
\hline $\begin{array}{l}\text { Sistem operasi yang digunakan sudah } \\
\text { usang }\end{array}$ & $\begin{array}{l}\text { - Teknologi yang digunakan untuk melakukan } \\
\text { penyerangan sistem semakin kuat seiring ber- } \\
\text { jalannya waktu }\end{array}$ \\
\hline Kebakaran & $\begin{array}{l}\text { - Pengamanan kabel yang membangun sistem E- } \\
\text { University yang tidak benar akan membuat resiko } \\
\text { kebakaran }\end{array}$ \\
\hline Malware & $\begin{array}{l}\text { - Keterlambatan dalam melakukan update antivi- } \\
\text { rus sehingga memungkinkan malware masuk } \\
\text { kedalam sistem }\end{array}$ \\
\hline Jamming & - $\quad$ jaringan wifi menggunakan wireless \\
\hline Serangan cyber & $\begin{array}{l}\text { - Penyusup menyesuaikan perilaku dalam me- } \\
\text { nanggapi pengawasan dan langkah-langkah } \\
\text { keamanan organisasi }\end{array}$ \\
\hline Media penyimpanan data rusak & $\begin{array}{l}\text { - } \text { Over heat pada pc } \\
\text { - } \text { Penggunaan yang berlebihan pada pc yang } \\
\text { digunakan } \\
\text { - Mematikan pc dengan cara menekan tombol } \\
\text { power bukan dari menu shutdown } \\
\text { (mematikan paksa) }\end{array}$ \\
\hline
\end{tabular}

\section{Pengenalan Kerentanan}

Setelah mengindentifikasi ancaman, tahap yang dilakukan selanjutnya adalah mengidentifikasi kerentanan yang terjadi pada sistem monitoring kegiatan belajar mengajar. Pengenalan kerentanan dapat dilihat pada tabel 3 .

\section{Analisis Penanganan Sistem}

Pengendalian-pengendalian didapat dalam wawancara telah dituangkan kedalam arsip yang mencakup semua standar-standar dan mekanisme dalam pengoperasian sistem monitoring kegiatan belajar mengajar yaitu dokumen SOP (Standard Operating Procedure).

Menentukan Kemungkinan Terjadi (Likelihood)

Setelah melakukan identifikasi kerentanan, selanjutnya menentukan bagaimana kemungkinan terjadi (likelihood) pada sistem monitoring kegiatan belajar mengajar. Kemungkinan terjadi ancaman pada sistem monitoring kegiatan belajar mengajardapat dilihat pada tabel 4 .

Tabel 4. Kemungkinan Terjadi (Likelihood)

\begin{tabular}{lc}
\hline \multicolumn{1}{c}{ Tipe Resiko } & $\begin{array}{c}\text { Tingkat kemungkinan } \\
\text { terjadi (Likelihood) }\end{array}$ \\
\hline $\begin{array}{l}\text { Pengguna sistem monitoring yang merupakan orang ter- } \\
\text { percaya melakukan penyerangan }\end{array}$ & Tinggi \\
\hline Sistem operasi yang digunakan sudah usang & Tinggi \\
\hline Kebakaran & Sedang \\
\hline Malware & Tinggi \\
\hline Jamming & Tinggi \\
\hline Serangan cyber & Sedang \\
\hline Media penyimpanan data rusak & Tinggi \\
\hline
\end{tabular}


DOI: https://doi.org/10.33330/jurteksi.v7i1.902

Available online at http://jurnal.stmikroyal.ac.id/index.php/jurteksi

Tabel 5 Konsekuensi Resiko

\begin{tabular}{|c|c|c|}
\hline Tipe Resiko & Dampak & $\begin{array}{c}\text { Tingkat } \\
\text { dampak resiko }\end{array}$ \\
\hline $\begin{array}{l}\text { Pengguna sistem monitoring yang } \\
\text { merupakan orang terpercaya } \\
\text { melakukan penyerangan }\end{array}$ & $\begin{array}{l}\text { Penyusup yang masuk dapat } \\
\text { melakukan pencurian data }\end{array}$ & Tinggi \\
\hline $\begin{array}{l}\text { Sistem operasi yang digunakan su- } \\
\text { dah usang }\end{array}$ & $\begin{array}{l}\text { Kerusakan parah pada sistem } \\
\text { yang mengakibatkan beberapa } \\
\text { atau semua fungsi pada sistem } \\
\text { tidak dapat dioperasikan, }\end{array}$ & Tinggi \\
\hline Kebakaran & $\begin{array}{l}\text { Rusaknya hardware dan } \\
\text { software yang digunakan untuk } \\
\text { mendukung sistem monitoring } \\
\text { kegiatan belajar mengajar }\end{array}$ & Tinggi \\
\hline Malware & $\begin{array}{llr}\text { - } & \text { Merubah tampilan pada } \\
\text { sistem monitoring } \\
\text { kegiatan belajar mengajar } \\
\text { - } & \text { Memunculkan iklan-iklan } \\
\text { spam pada sistem } \\
\text { monitoring kegiatan } \\
\text { belajar mengajar }\end{array}$ & Sedang \\
\hline Jamming & $\begin{array}{l}\text { Penyusup mengganggu } \\
\text { jaringan yang digunakan oleh } \\
\text { sistem monitoring kegiatan } \\
\text { belajar mengajar }\end{array}$ & Sedang \\
\hline Serangan cyber & $\begin{array}{l}\text { Mengunci sistem komput- } \\
\text { er dan data yang diserang }\end{array}$ & Sedang \\
\hline Media penyimpanan data rusak & $\begin{array}{l}\text { Kehilangan data penting yang } \\
\text { ada pada sistem }\end{array}$ & Tinggi \\
\hline
\end{tabular}

\section{Menganalisis Dampak Resiko}

Setelah melakukan identifikasi kemungkinan terjadi (likelihood), selanjutnya menentukan bagaimana dampak resiko yang akan terjadi pada sistem monitoring kegiatan belajar mengajar. Dampak resiko ancaman pada sistem monitoring kegiatan belajar mengajar dapat dilihat pada tabel 5 .

\section{Risk Determination}

Setelah melakukan identifikasi kemungkinan terjadi (likelihood) dan dampak resiko, selanjutnya dilakukan pengukuran seberapa tinggi atau seberapa rendahkah tingkat resiko yang terjadi pada sistem monitoring kegiatan belajar mengajar menggunakan skala pada matriks resiko. Hasil dari risk determination dapat dilihat pada tabel 6 .

\section{Rekomendasi Pengendalian}

Dari hasil penentuan tingkat resiko maka peneliti memberikan rekomendasi pengendalian bagaimana cara menghadapi ancaman-ancaman atau serangan-serangan yang dilakukan oleh hacker terhadap sistem monitoring kegiatan belajar mengajar. Rekomendasi pengendalian dapat dilihat pada tabel 7 . 
Available online at http://jurnal.stmikroyal.ac.id/index.php/jurteksi

Tabel 6. Penetapan Resiko

\begin{tabular}{|c|c|c|c|c|}
\hline Tipe Resiko & $\begin{array}{c}\text { Nilai peluang } \\
\text { Terjadi } \\
\text { (vulnerability) } \\
\end{array}$ & $\begin{array}{c}\text { Nilai } \\
\text { dampak }\end{array}$ & $\begin{array}{l}\text { Nilai } \\
\text { Resiko }\end{array}$ & $\begin{array}{l}\text { Tingkat } \\
\text { Resiko }\end{array}$ \\
\hline $\begin{array}{ll}\text { Pengguna sistem } & \text { monitoring } \\
\text { yang merupakan } & \text { orang ter- } \\
\text { percaya } & \text { melakukan } \\
\text { penyerangan } & \end{array}$ & $\begin{array}{c}\text { Tinggi } \\
(1,0)\end{array}$ & $\begin{array}{l}\text { Tinggi } \\
(1,0)\end{array}$ & 100 & Tinggi \\
\hline $\begin{array}{l}\text { Sistem operasi yang digunakan } \\
\text { sudah usang }\end{array}$ & $\begin{array}{l}\text { Tinggi } \\
(1,0)\end{array}$ & $\begin{array}{l}\text { Tinggi } \\
(1,0)\end{array}$ & 100 & Tinggi \\
\hline Kebakaran & $\begin{array}{c}\text { Sedang } \\
(0,5)\end{array}$ & $\begin{array}{l}\text { Tinggi } \\
(1,0)\end{array}$ & 50 & Sedang \\
\hline Malware & $\begin{array}{l}\text { Tinggi } \\
(1,0)\end{array}$ & $\begin{array}{l}\text { Sedang } \\
(0,5)\end{array}$ & 50 & Sedang \\
\hline Jamming & $\begin{array}{c}\text { Tinggi } \\
(1,0)\end{array}$ & $\begin{array}{c}\text { Sedang } \\
(0,5)\end{array}$ & 50 & Sedang \\
\hline Serangan cyber & $\begin{array}{c}\text { Sedang } \\
(0,5)\end{array}$ & $\begin{array}{l}\text { Sedang } \\
(0,5)\end{array}$ & 25 & Sedang \\
\hline Media penyimpanan data rusak & $\begin{array}{l}\text { Tinggi } \\
(1,0)\end{array}$ & $\begin{array}{l}\text { Tinggi } \\
(1,0)\end{array}$ & 100 & Tinggi \\
\hline
\end{tabular}

Tabel 7. Rekomendasi Pengendalian

\begin{tabular}{|c|c|c|c|}
\hline No. & Jenis Resiko & $\begin{array}{l}\text { Tingkat } \\
\text { Resiko } \\
\end{array}$ & Rekomedasi Pengendalian \\
\hline 1 & $\begin{array}{lrr}\begin{array}{l}\text { Pengguna } \\
\text { merupakan }\end{array} & \text { sistem } & \text { yang } \\
\text { percaya } & & \text { ter- } \\
\end{array}$ & Tinggi & Memperkuat firewall yang digunakan \\
\hline 2 & $\begin{array}{l}\text { Sistem operasi yang } \\
\text { digunakan sudah usang }\end{array}$ & Tinggi & $\begin{array}{l}\text { Lakukan update berkala untuk sistem } \\
\text { operasi yang digunakan }\end{array}$ \\
\hline 3 & Kebakaran & Sedang & $\begin{array}{l}\text { Gunakan pelindung kabel yang aman } \\
\text { dan instalasi kabel dengan benar }\end{array}$ \\
\hline 4 & Malware & Sedang & $\begin{array}{l}\text { Update plug in, update antivirus, } \\
\text { update versi software }\end{array}$ \\
\hline 5 & Jamming & Sedang & Gunakan teknik spread spectrum \\
\hline 6 & Serangan cyber & Sedang & $\begin{array}{l}\text { Memberikan password yang kuat dan } \\
\text { rahasia kepada semua pengguna, } \\
\text { firewall diperkokoh, backup data } \\
\text { berkala }\end{array}$ \\
\hline 7 & $\begin{array}{l}\text { Media penyimpanan data } \\
\text { rusak }\end{array}$ & Tinggi & 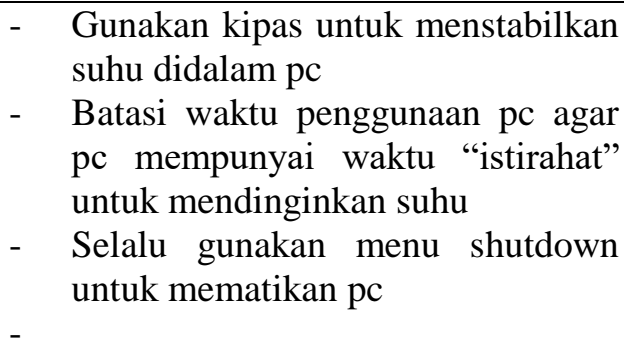 \\
\hline
\end{tabular}


Available online at http://jurnal.stmikroyal.ac.id/index.php/jurteksi

monitoring kegiatan belajar mengajar pada perguruan tinggi swasta dibuatlah tata cara bagaimana penanganan resiko-resiko dari penyerangan terhadap sistem yang dibuat berdasarkan rekomendasi bagaimana cara pengendalian terhadap ancaman-ancaman yang menyerang sistem. Dokumen hasil ini dapat berupa standar prosedur penanganan dari ancaman-ancaman dan resiko-resiko yang menyerang sistem.

\section{SIMPULAN}

Dalam proses penialain resiko pada penelitian ini menggunakan kerangka kerja NIST Special Publication 800-30r-1 yang terdiri dari penilaian resiko yaitu pengenalan karakteristik sistem, pengenalan ancaman, pengenalan kerentanan, analisis penanganan sistem, menentukan kemungkinan terjadi (likelihood), menentukan konsekuensi (impact), risk determination, merekomendasikan bagaimana melakukan pengawasan terhadap sistem. Untuk mengetahui resiko, peneliti melakukan wawancara kepada pengguna sistem. Dari hasil penilaian resiko terdapat delapan jenis resiko yang terjadi pada sistem monitoring kegiatan belajar mengajar. Resiko-resiko yang terjadi adalah orang dalam yang pernah mempunyai akses kedalam sistem, sistem operasi yang usang, kebakaran yang disebabkan human error, virus malware, jamming, serangan cyber, rusaknya media penyimpanan seperti hardisk yang ada pada PC yang digunakan.

\section{DAFTAR PUSTAKA}

I. Governance, "Penilaian Tingkat Kapabilitas Proses Tata Kelola Teknologi Informasi Dengan Cobit 5 Pada Domain Edm (Studi Kasus Di Pt. Nusa Halmahera Minerals)," 2016.

[2] N. Matondang, B. Hananto, And C. Nugrahaeni, "Analisis Tingkat Kesiapan Pengamanan Sistem Informasi," Jtip: Jurnal Teknologi
Informasi Dan Pendidikan, Vol. 12, No. 1, Pp. 51-55, 2019.

[3] A. A. Putra, O. D. Nurhayati, And I. P. Windasari, "Perencanaan Dan Implementasi Information Security Management System Menggunakan Framework Iso/Iec 20071," Jurnal Teknologi Dan Sistem Komputer, Vol. 4, No. 1, Pp. 60-66, 2016.

[4] B. Suzanto And I. Sidharta, "Pengukuran End-User Computing Satisfaction Atas Penggunaan Sistem Informasi Akademik," Jurnal Ekonomi, Bisnis \& Entrepreneurship, Vol. 9, No. 1, Pp. 16-28, 2015.

[5] I. Mashuri, "Pengembangan Manajemen Resiko Teknologi Informasi Pada Sistem Penerimaan Peserta Didik Baru (Ppdb Online) Kemdikbud Menggunakan Framework Nist Sp800-30," Surabaya: Theses Manajemen Teknologi Informasi-S2 Mmt, Its, 2015.

[6] S. Agustinus, A. Nugroho, And A. D. Cahyono, "Analisis Risiko Teknologi Informasi Menggunakan Iso 31000 Pada Program Hrms," Jurnal Resti (Rekayasa Sistem Dan Teknologi Informasi), Vol. 1, No. 3, Pp. 250-258, 2017.

[7] V. A. Prabawati, A. Rachmadi, And A. R. Perdanakusuma, "Analisis Risiko Teknologi Informasi Berbasis Risk Management Menggunakan Kerangka Kerja Octave-S Pada Unit Pengelola Sistem Informasi Dan Kehumasan (Psik) Fakultas Ilmu Komputer Universitas Brawijaya," Jurnal Pengembangan Teknologi Informasi Dan Ilmu Komputer EIssn, Vol. 2548, P. 964x, 2018.

[8] I. Maliki, "Manajemen Resiko Teknologi Informasi I Untuk Keberlangsungan Layanan Publik Menggunakan Framework Information Technology Infrastructure Library (Itil Versi 3)," In Seminar Nasional Aplikasi 
DOI: https://doi.org/10.33330/jurteksi.v7i1.902

Available online at http://jurnal.stmikroyal.ac.id/index.php/jurteksi

Teknologi Informasi (Snati), 2016.

[9] M. Rahardjo, "Metode Pengumpulan Data Penelitian Kualitatif," 2011.

[10] H. Hasanah, "Teknik-Teknik Observasi (Sebuah Alternatif Metode Pengumpulan Data Kualitatif IlmuIlmu Sosial)," At-Taqaddum, Vol. 8, No. 1, Pp. 21-46, 2017.

[11] Y. I. Meilani, D. Syamsuar, And Y. N. Kunang, "Assessment Resiko Teknologi Pada Implementasi Sistem Informasi Akademik E-University,"
Jurnal Bina Komputer, Vol. 1, No. 1, Pp. 54-60, 2019.

[12] R. Andryani, "Pengukuran Risiko Pada Penerapan Cloud Computing Untuk Sistem Informasi (Studi Kasus Universitas Bina Darma)," Jurnal Teknologi Technoscientia, Pp. 173179, 2016.

[13] S. Nist, "800-30, Revision 1," Guide For Conducting Risk Assessments, 2012. 